\title{
AN EXAMPLE OF RATIONAL DERMANYSSUS GALLINAE CONTROL - PULCAP
}

\author{
Aleksandar Pavlićevićc ${ }^{1 *}$, Radomir Ratajac ${ }^{2}$, Igor Stojanov ${ }^{2}$, Ivan Pavlović ${ }^{3}$ \\ "AVES MIT” LLC, Subotica-Bajmok, Cluster “Dermanyssus gallinae", Serbia \\ ${ }^{2}$ Scientific Veterinary Institute „Novi Sad“, Novi Sad, Serbia \\ ${ }^{3}$ Scientific Veterinary Institute of Serbia, Belgrade, Serbia
}

Abstract

The irrational control of Dermanyssus gallinae ectoparasites (De Geer, 1778 ) in intensive livestock can cause health problems, economic damage, and can also toxicologically harm the health of humans and the environment. Formulation P 547/17 (Pulcap) is a new generation of inert matter (an oil). In Pulcap formulation and technology, the fulfilment of rigorous criteria for rational control of D. gallinae were tested and present in this paper. Those criteria are the following: the safety of the preparation (i.e. the preparation is non-toxic); the feasibility of application of the preparation in facilities, for handling transport cages, on used cages and equipment, as well as in inhabited buildings; the method of application - the preparation is applied by spray method (external application). The aim of the application was also considered. It is to make the control effective, on the condition that eradication is feasible. Then, the conditionality, which imply that the application of this preparation requires fulfilling hygienic conditions, break of production in facilities, a certain temperature and professional approach to it. The efficacy of the preparation is another important criterion. It implies that the clinical results of the application have been monitored in different conditions at different time intervals. It has been proven that there is no resistance to this preparation. The disadvantages of the preparations were also observed. It is the absence of prolonged action on absorbent surfaces, the delay in starting the egg bar and discharging, which increases contamination. The whole program / plan of long-term control has been developed. The cost-effectiveness of the product is the ratio of price and efficiency on an annual level. Eradication is the most economical method of controlling D. gallinae, which relieved farmers from all further costs. There is a great

${ }^{1 *}$ Corresponding author: zemljadrveca@gmail.com 
challenge for each type of $D$. gallinae control, especially the rational one. Reconsidering and further development of the approach of rational control is a way to improve the control of D. gallinae, which we want to encourage.

Key words: rational control, Dermanyssus gallinae, PULCAP

\title{
PRIMER RACIONALNE KONTROLE DERMANYSSUS GALLINAE -PULCAP
}

\author{
Aleksandar Pavlićević1, Radomir Ratajac ${ }^{2}$, Igor Stojanov², Ivan Pavlović ${ }^{3}$ \\ 1"AVES MIT" LLC, Subotica-Bajmok, , Klaster “Dermanyssus gallinae", Srbija \\ ${ }^{2}$ Naučni institut za veterinarstvo "Novi Sad", Novi Sad, Srbija \\ ${ }^{3}$ Naučni institut za veterinarstvo Srbije, Beograd, Srbija
}

\section{Kratak sadržaj}

Neracionalna kontrola ektoparazita Dermanyssus gallinae (De Geer, 1778) u intenzivnom živinarstvu prouzrokuje zdravstvene probleme i ekonomske štete, a može i toksikološki da naškodi zdravlju čoveka, živine i životnoj sredini. Za razliku od insekticida, formulacija P 547/17 (Pulcap) je nova generacija inertnih materija, koja spada u grupu netoksičnih jedinjenja a formulacija koja se primenjuje je u vidu vodene emulzije. U cilju racionalne kontrole D. gallinae sa P 547/17 (Pulcap) vršena su ispitivanja ispunjenost više kriterijuma koja bi potvrdila efikasnost preparata. Kriterijume koje smo ispitivali bili su sledeći: Bezbednost preparata, odnosno da je preparat netoksičan; Mogućnosti primene u pripremi objekata, za tretiranje transportnih kaveza, polovnih kaveza i opreme, kao i u naseljenim objektima; Vreme primene koje se baziralo na vremenu preventivnog delovanja; Način primene - preparat se aplikuje sprej metodom, što predstavlja spoljašnju primenu; Cilj primene - da suzbijanje bude visoko efikasno, a po sticanju uslovnosti da je moguća eradikacija; zatim uslovnost, što je podrazumevalo da je za primenu preparata neophodno obezbediti higijenske prilike, odmor objekta, određenu temperaturu i stručnu primenu; Efikasnost preparata što podrazumeva da su klinički rezultati primene praćeni $\mathrm{u}$ različitim uslovima pripreme objekata pred naseljenje u različitim vremenskim intervalima; Rezistenciju i druge adaptivni mehanizme pri čemu je dokazano da ih preparat ne stvara. Praćeni su i nedostaci preparata i to je izostanak produženog delovanja na upijajućim površinama, zastoj 
u pokretanju trake za jaja i izđubravanju, što povećava onečišćenje. Razvijen je ceo program/ plan dugoročne kontrole. Ekonomičnost preparata predstavlja odnos cene i efikasnosti na godišnjem nivou. Eradikacija je najekonomičniji vid kontrole $D$. gallinae, kojom se farmer oslobađa svih daljih troškova. Postoji velik izazov za svaku vrstu kontrole D. gallinae, a posebno onu racionalnu. Preispitivanje i dalji razvoj racionalne kontrole, je put unapređenja kontrole D. gallinae, koji želimo da podstaknemo.

Ključne reči: racionalna kontrola, Dermanyssus gallinae, PULCAP

\section{INTRODUCTION}

Non-rational control of the ectoparasite Dermanyssus gallinae (De Geer, 1778) in the intensive poultry industry causes health problems and economic loss (Emous, 2005; 2017), and it can cause toxicological harm to human and poultry health and the environment (Giangaspero et al., 2011; Marangi et al., 2012; Giangaspero, 2017). This problem has existed for several decades and it has a high prevalence (Sparagano et al., 2009; Mul et al., 2016), with a tendency of further increase.

\section{CRITERIA FOR RATIONAL D. gallinae CONTROL}

According to the World Health Organization (WHO), rational pharmacotherapy requires that "patients receive medications appropriate to their clinical needs, in doses that meet their own individual requirements, for an adequate period of time, and at the lowest cost to them and their community". Based on the general definition and specific demands of this issue, we propose the following criteria for rational D. gallinae control:

1. 1. Safety

2. Feasibility of application

3. Time of application: preventive or curative approach

4. Method of application

5. Aim of application: suppression or eradication

6. Necessary conditions

7. Efficacy: laboratory and clinical

8. Resistance and other adaptive mechanisms

9. Disadvantages

10. Long-term and comprehensive control plan: the program

11. Cost-effectiveness 
The P 547/17 formulation (Pulcap) is a new generation of inert substances, which is applied in the form of water emulsion. It is registered as a product for general use. The criteria of rationality regarding Pulcap formulation and technology are the following:

\section{Safety}

Synthetic, neurotoxic chemical compounds - acaricides or insecticides are the predominant type of D. gallinae control. The first problem with these compounds is their potential toxicity to humans, animals and the environment.

Unlike insecticides, Pulcap formulation falls into the category of non-toxic compounds. In addition to this, its application focuses on the poultry housing preparation, which prevents any kind of exposure or stress. Only in cases when the necessary conditions have not been met, application is suggested with the poultry inside. In this situation, the formulation's efficacy helps to avoid excessive use. Pulcap formulation and technology fulfils the highest safety criteria.

In general, herbal products are an appropriate choice regarding safety. The safety of $\mathrm{SiO} 2$-based products depends on the content of a specific formulation and on the application technology itself.

\section{Feasibility of application}

Pulcap formulation is applied in the preparation of (empty, cleaned and disinfected) poultry houses, treatment of poultry transport cages, and treatment of used cages and equipment (Fig 1). If necessary, it can be used in a full house, with poultry inside.

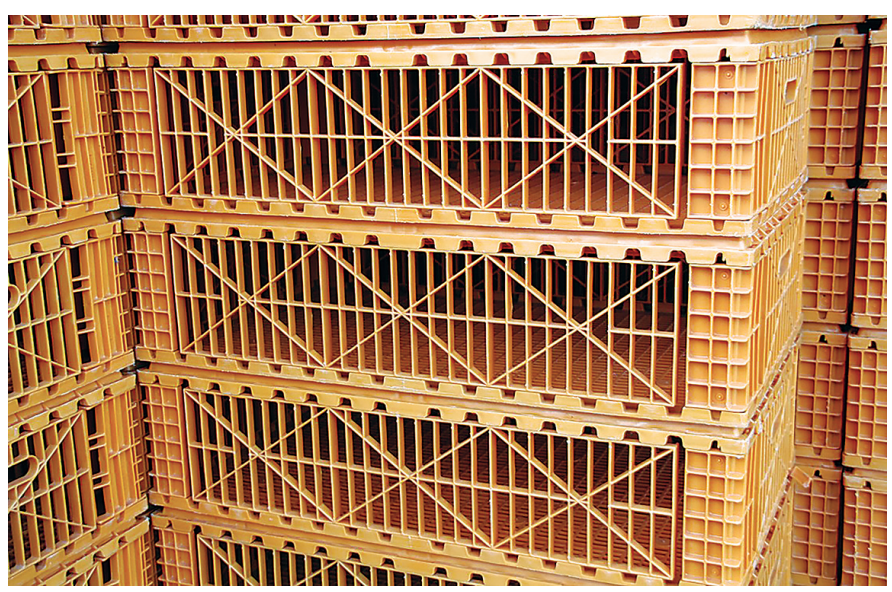

Figure 1. The transport cages for poultry are used for the colonization and emigration flock 
Veterinary medicine fluraraner (Exzolt) can be used only for the treatment of poultry, while other insecticides for external use can also be used for housing preparation. Rational application of insecticides on transport cages is problematic due to very demanding conditions for the detection of resistance. The situation is similar with used cages and equipment - if the examination for resistance is not performed on the infested flock before the placement.

Selected $\mathrm{SiO}_{2}$ formulations (combination of powder and liquid form), can be a good choice for housing preparation if the necessary conditions have been met. They are also used in production with a significantly lower effect (Fig 2). They are not appropriate for application on plastic transport cages, while the treatment of used cages and equipment depends on a specific situation. Herbal formulations are prepared primarily for the application through poultry's feed and water.

\section{Time of application: preventive or curative approach}

The current concept of application of insecticides and herbal formulations is based on the curative approach. As opposed to this, Pulcap is based on the preventive action, during pre-placement housing preparation (Fig 3). The preventive approach should be chosen because of the following: it prevents exposure (of poultry, eggs, staff) and ensures the safety of the procedure; it maximizes the effect; it prevents damage; it prevents the transmission of $D$. gallinae; it prevents the spreading and development of the disease; it decreases the possibility of resistance development; it is cost-effective; and the flocks are treated only if necessary. The treatment of the flock as the primary concept of D. gallinae control is wrong, because it can be successfully prevented (avoided). Instead of biosecurity measures, farmers are offered Q - Perch Vencomatic equipment for active D. gallinae control (van de Ven, 2016).

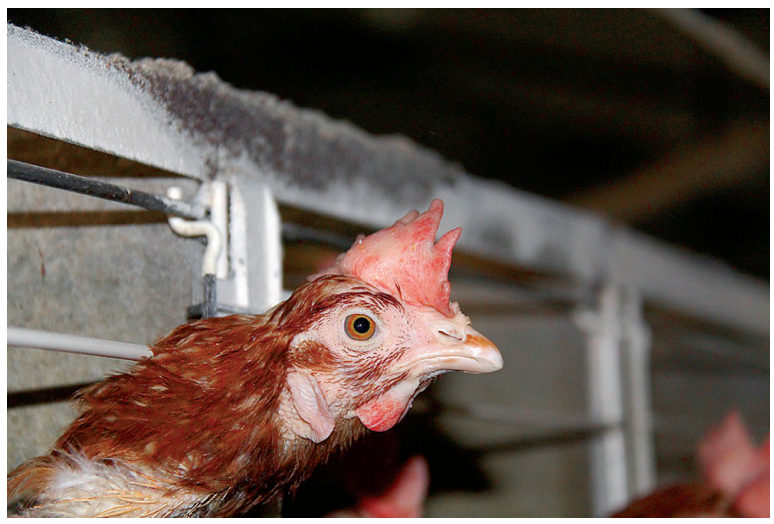

Figure 2. Highly infested flocks with D. gallinae 


\section{Method of application}

The correct application technology (D. gallinae control has been focused only on products) has in most cases been missing in practice so far, thus significantly contributing to the existing negative tendency of Dermanyssosis. Timely procedure and comprehensive and systematic application are necessary.

External application by spraying is the most common method of application. Compared to this, per os application has an advantage because it is simple to perform, but at the same time, it is much more complicated regarding safety (which is a much more important criterion), since the formulation is incorporated directly into the poultry's body and, thus, into human food.

Machine application technology has been developed for Pulcap formulation. It includes mounting a structure with nozzles, which systematically applies the water emulsion on the targeted places. This way, a high operability is enabled and three persons can treat the capacity of up to 100,000 layers in the cage system per day (Fig 4). At the ends of batteries, in small farms and other types of layer housing, manual application can be implemented.

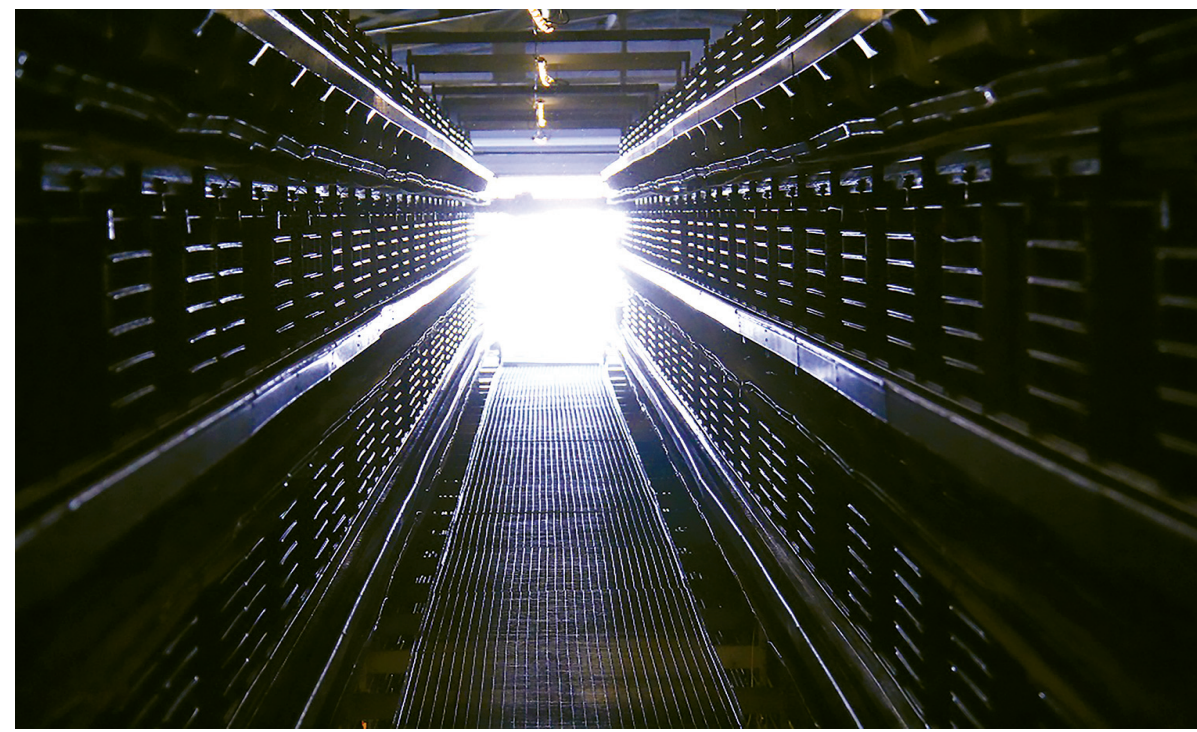

Figure 3. Poultry house with enriched caging prepared before the flock placement, using Pulcap technology. 


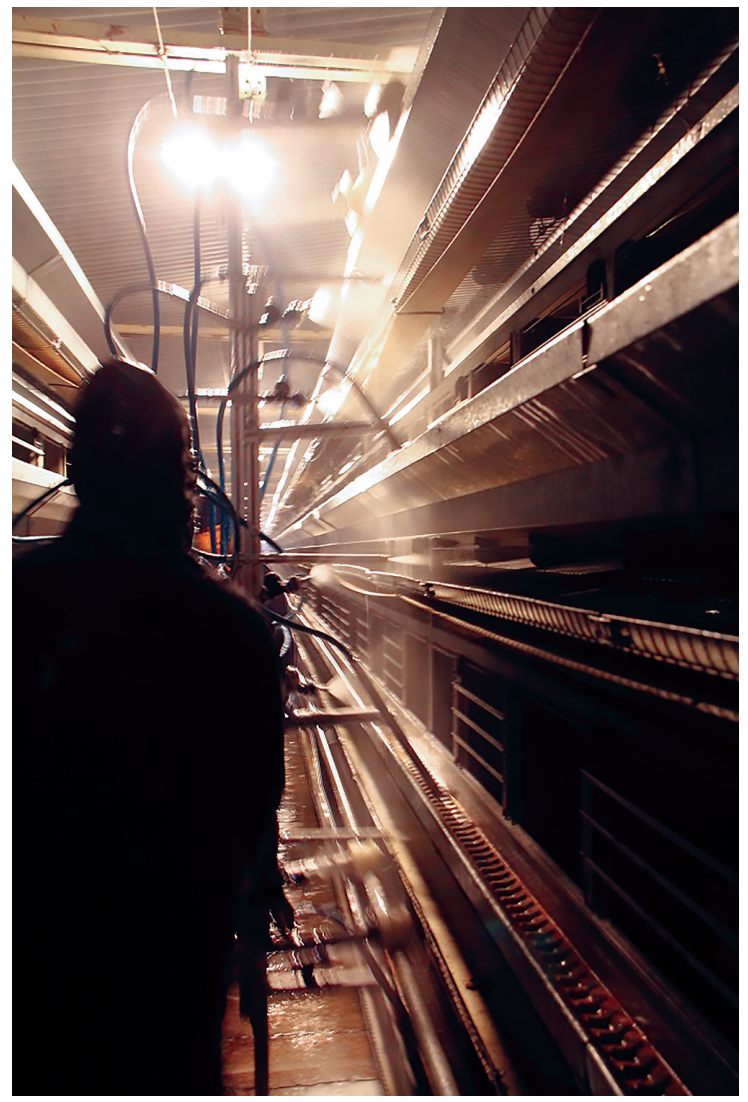

Figure 4. Application of aqueous emulsion formulation Pulcap

\section{Aim of application: suppression or eradication}

The current practice is based on D. gallinae suppression. Therefore, D. gallinae in intensive poultry production persists and spreads, and farmers have perpetual expenses, which constantly rise. D. gallinae eradication from the production facilities of the poultry industry is possible and justified for various reasons (Pavlićević et al., 2018a). It provides the highest level of long-term safety and cost-effectiveness in D. gallinae control, as well as in the control of infectious diseases. Suppression should only be a temporary phase until the conditions for eradication are created. The D. gallinae problem can be solved and it does not have to exist in intensive poultry production. It has been proven that eradication can be achieved with Pulcap technology (Pavlićević et al., 2018b). 


\section{Necessary conditions}

Application of Pulcap technology requires hygienic conditions, housing downtime (14 days or longer for eradication), temperature above freezing, and professional application. Other approaches in D.gallinae control have similar requirements and conditions (to a greater or lesser extent). The essence of the problem is that most often conditions and requirements are not sufficiently specified nor is abiding by them emphasized enough.

\section{Efficacy}

Laboratory tests provide important, but limited guidelines for the biological efficacy against D. gallinae. It is very important for insecticides to have specification for a concrete infestation and to be based on up-to-date information. Resistance development has eliminated most of the insecticides used so far, so a lot of older data on efficacy testing is no longer relevant. The latest insecticide is fluralaner (Exzolt). It is used to treat poultry and is applied through drinking water twice over a period of 7 days. Acaricide efficacy of fluralaner applied in this way over 15 days is between $99.3 \%$ and 100\% (Brauneis et al., 2017). It is estimated that this veterinary medicine achieves suppression of over $90 \%$ in an average period of 8 months (56 - 238 days) (Thomas et al., 2017).

The efficacy of different $\mathrm{SiO} 2$-based formulations varies significantly (Maurer et al., 2009; Schulz, 2014; Pavlićević et al., 2018c). For this reason it is necessary to choose the formulation based on efficacy tests. Moreover, SiO2based formulations have extremely demanding application, small acaricide capacity per surface unit and slow effect, so even the lethally exposed mites can lay fertile eggs. Their action is affected by dirt and humidity (Pavlićević et al., 2017,2018 b). Their application is optimized in the control program, by combined application of powder and liquid forms in an empty poultry house and with housing downtime in the temperature conditions when mites are active (Pavlićević et al., 2017, 2018b).

The most important disadvantages of $\mathrm{SiO} 2$-based formulations are eliminated by the new generation of inert substances - Pulcap. It is a water emulsion of inert oils, it has good applicability, distribution, a quicker effect on the exposed D. gallinae, higher mortality per surface unit, and extremely long prolonged effect on unabsorbent surfaces. Clinical results with all the conditions fully met, after the application of $20 \%$ Pulcap water emulsion, were negative in 8 poultry houses with cage rearing system (a total capacity of 144,000 chicks) during 6 months, over the period after rearing two flocks in each (the 
observation is ongoing) (Fig 5). Another example was in partly met conditions in 7 poultry houses with the capacity of 241,360 layers, in a cage system (conventional and enriched). In addition to the housing preparation with 20\% Pulcap water emulsion, over the production period of one year, another treatment with $10 \%$ water emulsion was necessary. In three houses with the total capacity of 103,000 hens, only one preparatory treatment was sufficient for the suppression effect over the production period of one year. However, in cases when conditions were fully met, there are examples of complete eradication from the production facilities (so far confirmed in 2 houses with conventional cage system, a total capacity of 6,000 hens). In the case of application in a full house, one treatment with 10\% Pulcap water emulsion provides 3 to 4 months of suppression on average. However, two consecutive treatments increase the efficacy in a full house (up to 5-10 months, according to the experience so far). Based on the recorded results, Pulcap technology belongs to the efficient methods of D. gallinae control. Nevertheless, we believe that the technology has not been optimized yet and that even higher efficacy than the one recorded so far can be achieved. Optimization tests are ongoing, and the results are expected by the end of 2020 .

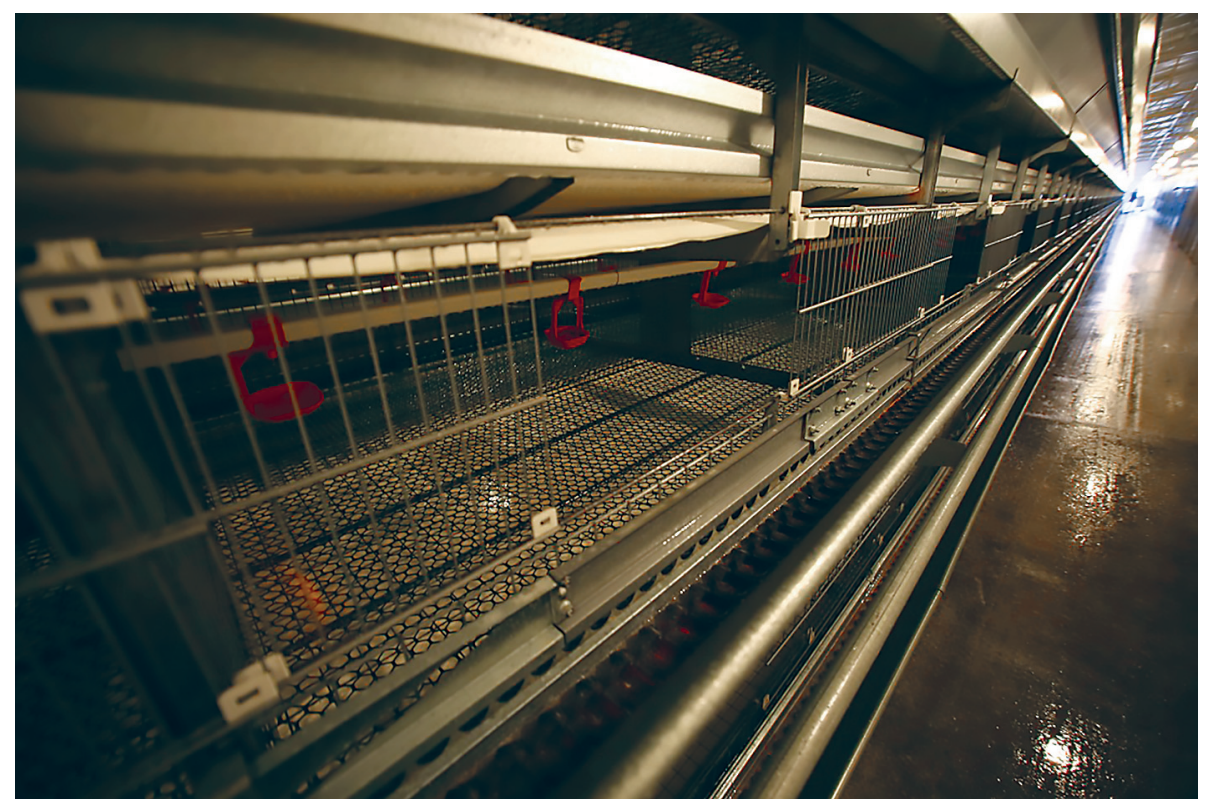

Figure 5. The cages for rearing hens treated technology Pulcap 
During and after the application of phytorepellents, feeding and reproduction of D. gallinae were reduced (Puvača et al., 2016). The problem is that the number of mites per hen still increases over time, so the numbers neutralize the positive effect achieved so far. In addition to this, as a result of the application of phytorepellents on poultry, the mites increasingly attack farm staff. Due to the (significant) lack of cidal or real repelling effect (which would stop the reproduction completely), phytorepellents are actually only partial repellents. Such characteristics qualify them primarily as an auxiliary product in $D$. gallinae control. A good choice of this product can be justified if it is necessary to maintain a tolerable, cost-effective level of infestation at the end of the flock's production period, until the flock is removed from the house.

\section{Resistance and other adaptive mechanisms}

Another problem of predominantly treating D. gallinae with insecticides is resistance (Abbas, 2014; Pavlićević et al., 2016). So far there has not been a regular monitoring of resistance in D. gallinae control. In that aspect, acaricide application in $D$. gallinae control has so far not been rational. In the application of $\mathrm{SiO} 2$ formulations, adaptations in D. gallinae behavior have been recorded - they moved to places which are not accessible for application.

Unlike acaricides, it is believed that the development of chemoresistance to Pulcap formulation is not possible, and due to a better distribution neither is the development of other adaptive mechanisms which have been recorded in $\mathrm{SiO} 2$ formulations (Fig 6). Efficacy of Pulcap formulation and technology will not weaken over time.

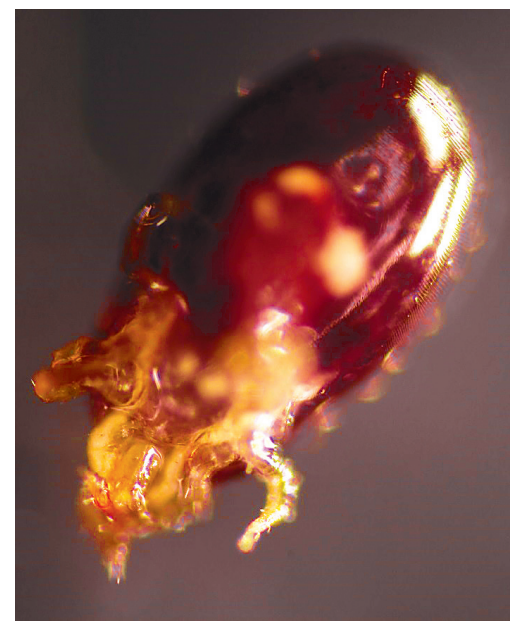

Figure 6. The physical effect of the Pulcap formulation on D. gallinae 


\section{Disadvantages}

Pulcap formulation does not have prolonged effect on absorbent surfaces, such as a concrete floor. This flaw requires repeated application, so that the subsequently exposed mites can also be affected. Application of Pulcap water emulsion can cause intermittent movement of conveyor and manure belts, which can be fixed by applying adsorptive powder (Fig 7). Cages and equipment get dirty to a somewhat greater extent, but hygienic conditions can be maintained.

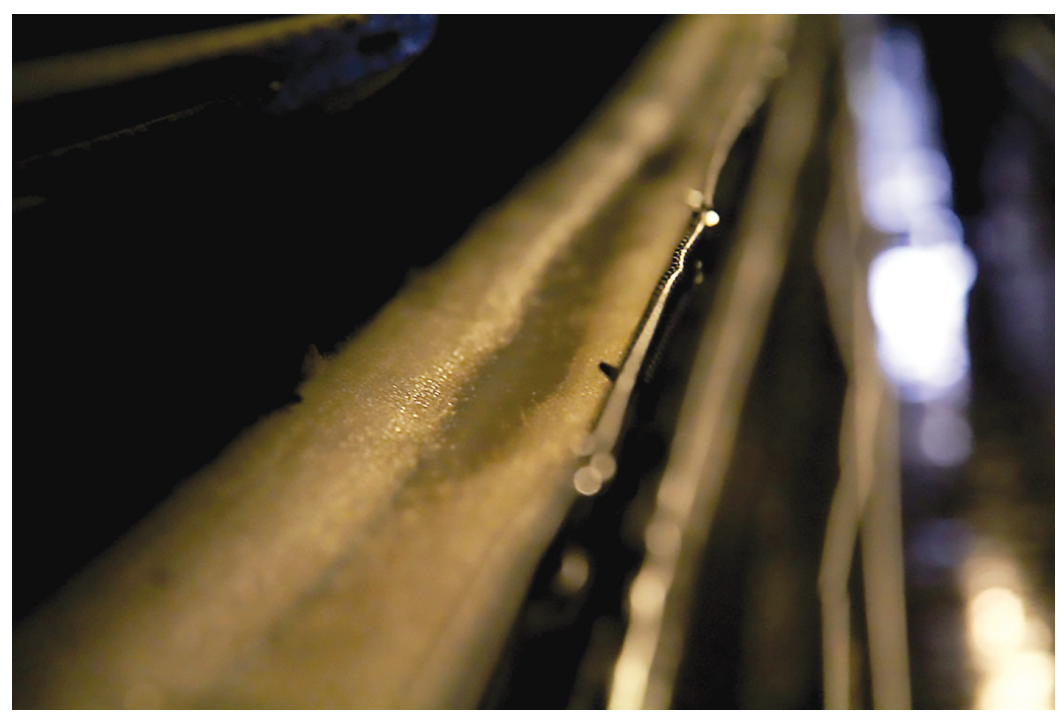

Figure 7. A tray for the transport of eggs exposed to aqueous emulsion of the Pulcap formulation

The disadvantages of $\mathrm{SiO} 2$ formulations and technology are the following: complex application and equipment, limited distribution, abrasive effect on cages and equipment, and dust in the application of powder forms (Pavlićević et al., 2018c).

\section{Long-term control plan: the program}

In addition to the application technology, we have also designed a complete program based on Pulcap formulation and control technology. The program provides a comprehensive approach and maximizes the principles of preventive medicine and rational control through the short-term goal of highly ef- 
ficient and safe suppression and the long-term goal of D. gallinae eradication and introduction of biosecurity measures (Pavlićević et al., 2018b). Another important element of the program is the environment and simplification of its conditions (Pavlićević et al., 2019). The program will produce its full effect only when it is implemented systematically, on a wider area, horizontally and vertically (parent flocks, rearing, production), which requires institutional support. For new and non-infested farms and poultry houses, the program is based on biosecurity - prevention of mite introduction.

\section{Cost-effectiveness}

The cost of a product and technology can be correctly estimated only through its cost-effectiveness ratio. A proposed estimation of products and methods for D. gallinae control is the annual expenditure (during the regular flock production period). The control program, which enables eradication from the production facilities and introduction of biosecurity measures, is the most cost-effective type of D. gallinae control, which eliminates any further expenditures for the farmer.

\section{Other}

Adequate prerequisites for the rational control are detection and monitoring are necessary because they provide a relevant insight into the presence of D. gallinae infestation, its intensity and extensity (Pavlićević et al., 2007, 2018b).

The rational control must be up-to-date. Therefore, it is conditioned by regular periodic comparative assessments of formulations and methods for control, as well as providing timely information for experts and farmers.

\section{CONCLUSIONS}

Having analyzed the 11 criteria of rational control and compared it to the most important current solutions, we found that Pulcap formulation and technology is an example of rational control of D. gallinae. The use of non-toxic substances in prevention, with proven high efficacy creates the necessary basis for the fundamental improvement of D. gallinae control. There are disadvantages, which are important to be minimized with further development and, as much as possible, to be avoided or totally eliminated in the end. 


\section{REFERENCES}

1. Abbas R.Z., Colwell D.D., Iqbal Z., Khan A. 2014. Acaricidal drug resistance in poultry red mite (Dermanyssus gallinae) and approaches to its management. Worlds Poultry Science Journal, 70, 113-24;

2. Brauneis M.D., Zoller H., Williams H., Zschiesche E., Heckeroth A.R. 2017. The acaricidal speed of kill of orally administered fluralaner against poultry red mites (Dermanyssus gallinae) on laying hens and its impact on mite reproduction. Parasites \& Vectors, 10, 594. doi: 10.1186/s13071-0172534-5 PMCID: PMC5712167 PMID: 29197422;

3. Emous Van R. 2005. Wage war against the red mite. Poultry international, 44 (11), 26-33;

4. Emous Van R. 2017. Verwachtte schade bloedluis 21 miljoen euro. Pluimveeweb. nl.. https://www.pluimveeweb.nl/artikelen/2017/01/schadebloedluis21-miljoen-euro/;

5. Giangaspero A., Marangi M., Pati S., Cafiero M.A., Camarda C., Sparagano O.A.E. 2011. Investigating the presence of acaricide residues in laying hens naturally infected by the red mite Dermanyssus gallinae. In Book of Abstracts, The 12th Asean food conference 2011, BITEC Bangna, Bangkok, Thailand, 27;

6. Giangaspero A., Bartley K., Mul M., Papadopoulous E., Roy L., Horvatek Tomic D., Sparagano O. 2017. The anarchy in chemical control of Dermanyssus gallinae, and the need to establish specific EU regulations: the efforts of a COST Action. In Book of Abstract, WVPA XXth Congress 2017, Edinburgh, UK, 201;

7. Marangi M., Morelli V., Pati S., Camarda A., Cafiero M.A. 2012. Acaricide residues in laying hens naturally infested by red mite Dermanyssus gallinae. PLoS ONE, 7(2), e31795. doi: 10.1371/journal.pone.0031795;

8. Maurer V., Perler E., Heckendorn F. 2009. In vitro efficacies of oils, silicas and plant preparations against the poultry red mite Dermanyssus gallinae. Experimental and Apply Acarology, 48 (1-2):31-41. doi: 10.1007/s10493009-9254-2;

9. Mul M. 2016. Fact sheet: The Poultry Red Mite, Dermanyssus gallinae (De Geer, 1778). A small pest that packs a big punch 2013. https://www.researchgate.net/publication/258553789_Fact_sheet_Poultry_Red_Mite_in_ Europe

10. Pavlićević A., Pavlović I., Stajković N. 2007. Method for early detection of poultry red mite Dermanyssus gallinae (DeGeer, 1778). Biotechnology in Animal Husbandry, 23 (3-4), 119-127; 
11. Pavlićević A., Pavlović I., Stajković N. Bratislav P. 2016. Evidence for Resistance to Carbaryl in Poultry Red Mites from the Republic of Serbia and Montenegro. Scientific Papers: Animal Science and Biotechnologies, 49 (1), 222-225;

12. Pavlićević A., Ratajac R., Dotlić M., Stojanov I., Pavlovic I. 2017. An innovative formulation of paraffin and silicone oils for the control of the red poultry mite (Dermanyssus gallinae) - examination of the efficiency under laboratory conditions. Arhiv veterinarske medicine, 10 (2), 63-79;

13. Pavlićević A., Radomir R., Horvatek Tomić D., Stojanov I., Pavlović I. 2018a. Dermanyssus gallinae eradication approach - application of inert compounds and integral animal health protection. Arhiv veterinarske medicine, 11 (1), 3-15;

14. Pavlićević A., Ratajac R., Stojanov I., Pavlovic I. 2018b. Program control of poultry red mite Dermanyssus gallinae, today. Arhiv veterinarske medicine, 11 (2), 71-88;

15. Pavlićević A., Ratajac R., Stojanov I., Pavlovic I. 2018c. Innovative formulation of paraffin and silicon oils for the control of poultry red mite (Dermanyssus gallinae) - 3. Comparative Clinical Examination of Efficacy with Active Matter SiO2. Invention Journal of Research Technology in Engineering \& Management, 2 (10), 24-30;

16. Pavlićević A., Pavlović I., Ratajac R., Popović D., Davidović B., Krnjajić D. 2019. Poultry welfare in terms of poultry red mite (Dermanyssus gallinae) impact and control. Biotechnology in Animal Husbandry, 35 (1), 1-11;

17. Puvača N., Petrović A., Jurišić A., Ljevnaić Mašić B., Ivanović I., Kostadinović Lj., Nikolova N., Popović S. 2016. Effects of RIDofMITE in laying hens nutrition as a repellent of red mite (Dermanyssus gallinae, De Geer, 1778). In Book of Abstracts, International Conference "State-of-the-Art technologies: Challenge for the Research in Agricultural and Food Science", Belgrade, Serbia, 41;

18. Schulz J. 2014. Maßnahmen zur Bekämpfung der Roten Vogelmilbe (Dermanyssus gallinae) in der ökologischen Legehennenhaltung. InauguralDissertation zur Erlangung des Grades eines Doktors der Veterinärmedizin an der Freien Universität Berlin. Berlin, Journal-Nr.: 3702;

19. Sparagano O.A.E., Pavlićević A., Murano T., Camarda A., Sahibi H., Kilpinen O., Mul M., van Emous R., le Bouquin S., Hoel K., Cafiero M.A. 2009. Prevalence and key figures for the poultry red mite Dermanyssus gallinae infections in poultry farm systems. Experimental and Apply Acarology, 48, 3-10;

20. Thomas E., Chiquet M., Sander B., Zschiesche E., Flochlay A.S. 2017. Field 
efficacy and safety of (Dermanyssus gallinae) infestations in commercial flocks in Europe. Parasites \& Vectors, 10, 457. doi: 10.1186/s13071-0172390-3;

21. Van de Ven D. 2016. Q-perch, electronic control of red mite. Vencomatic Group. In Book of Abstracts, $2^{\text {nd }}$ COST Conference and Management Committee (MC) Meeting. COST Action FA1404. Improving current understanding and research for sustainable control of the poultry red mite Dermanyssus gallinae (COREMI), Zagreb, Croatia, 36.

Submitted: 02.06.2019.

Accepted: 18.06.2019. 